\title{
Physico-Chemical Properties of Volcanic Soils under Different Perennial Plants from Upland Area of Mt. Merapi, Indonesia
}

\author{
DOI: $10.18196 /$ pt.2019.098.93-102
}

\author{
Retno Kartikawati, Eko Hanudin*, Benito Heru Purwanto \\ Department of Soil Science, Faculty of Agriculture, Universitas Gajah Mada, \\ JL. Flora, Bulaksumur, Karang Malang, Caturtunggal, Kec. Depok, Kabupaten Sleman, Daerah Istimewa Yogyakarta 55281, Indonesia \\ *Coresponding author, email: ekohanudin@ugm.ac.id
}

\begin{abstract}
Vegetation recovery is essential in land restoration after the eruption of Mount Merapi in 2010. Vegetation is a source of organic material that produces root exudate containing organic acids. These acids accelerate the dissolution process of volcanic material so that it affects the soil characteristics. This study was conducted to analyze the effect of four types of perennial plants on soil chemical and physical characteristics. The soil samples were taken on the area planted with cinnamon, albizia, bamboo, and acacia, at depths of $0-10 \mathrm{~cm}, 10-20 \mathrm{~cm}, 20-30 \mathrm{~cm}, 30-40 \mathrm{~cm}$, and $40-50 \mathrm{~cm}$. The soil chemical analysis carried out included pH H2O, pH KCl, pH NaF, C-organic, Humic acid and Fulvic acid, cation exchange capacity, Ca, Mg, K, Na, available P, base saturation, and particle size distribution. The results show that pH H2O, pH KCl, C-organic, humic acid and fulvic acid, CEC, K, Na, Ca, Mg, available P, base saturation, and particle size distribution were significantly affected by vegetation type. Meanwhile, the pH of NaF was not significantly influenced by vegetation type. Cinnamon is a plant that gives the strongest influence in the improvement of soil chemical-physical properties compared to the other three types of vegetation. Therefore cinnamon is quite prospective plant to be developed for post-eruption land reclamation.
\end{abstract}

Keywords: Soil physico-chemical properties, Volcanic soil, Perennial plants, Mt. Merapi

\section{ABSTRAK}

Rekaveri vegetasi berperan penting dalam proses pemulihan lahan pasca erupsi Gunung Merapi tahun 2010. Vegetasi merupakan sumber bahan organik dan menghasilkan eksudat akar yang mengandung asam-asam organik. Asam-asam tersebut mempercepat proses dissolusi material vulkanik sehingga berpengaruh terhadap karakteristik tanah. Penelitian ini dilakukan untuk mengungkap pengaruh empat macam tanaman tahunan terhadap karakreristik fisika dan kimia tanahnya. Sample tanah diambil di bawah tegakan tanaman kayu manis, sengon, bambu dan akasia, masing-masing pada kedalaman 0-10 cm, 10-20cm, 20-30cm, 30-40cm dan 40-50cm. Analisis kimia tanah yang dilakukan meliputi antara lain yaitu pH-H2O, pH-KCl, pH-NaF, C-organik, asam humat dan fulvat, kapasitas pertukaran kation, Ca, Mg, K, Na, P-tersedia, kejenuhan basa dan sebaran ukuran partikel. Hasil penelitian menunjukkan bahwa pH-H2O, pH-KCl, C-organik, asam humat dan asam fulvat, KPK, K, Na, Ca, Mg, P tersedia, kejenuhan basa dan sebaran ukuran partikel secara nyata dipengaruhi oleh tipe vegetasi. Sedangkan pH NaF secara tidak nyata dipengaruhi oleh tipe vegetasi. Kayu manis merupakan tanaman yang memberikan pengaruh paling kuat dalam perbaikan sifat kimia-fisik lahan dibandingkan ketiga tipe vegetasi lainnya. Oleh karena itu kayu manis cukup prospektif untuk dikembangkan sebagai tanaman untuk rekaveri lahan pasca erupsi.

Kata Kunci: Sifat fisiko-kimia tanah, Tanah volkanik, Tanaman tahunan, Gunung Merapi

\section{INTRODUCTION}

The eruption of Mount Merapi in 2010 was the largest eruption during the last hundred years (Surono et al., 2012). The eruption released volcanic material composed of various rocks, sands, and silts (Newhall, 2000; Voight, 2000). The eruption was considered to be detrimental because it caused the surrounding vegetation to die and damaged the agricultural land. However, on the other hand, the volcanic material influenced the rejuvenation process and improved the surrounding soil fertility (Anda et al., 2012; Fiantis et al., 2009). Natural succession commonly occurs post-eruption; therefore, the surrounding area of Merapi is covered with various plants now. In the process of natural succession, vegetation plays a role in the dissolution of volcanic materials. Vegetation produces root exudates of low molecular weight organic acids (e.g., oxalic acid, citric acid, malic acid). In addition, vegetation is a source of organic materials whose humification results in high molecular weight acids (e.g., humic acid and fulvic acid). The organic acids produced by the vegetation will accelerate the dissolution of volcanic material. The natural phenomenon of post-eruption of Merapi in 2010 
is an exciting topic, but the studies related to this topic are still limited.

After the eruption of Mount Merapi in 2010, several types of plants such as cinnamon (Cinnamomum burmanni), albizia (Albizia chinensis), bamboo (Gigantochloa apus Kurz.), and acacia (acacia decurrens) has been found in the surrounding area. The plants grow naturally and some are cultivated by farmers. These plants affect the chemical and physical characteristics of the soil (Aweto, 1981). Different plant morphology and root physiology will results in different nutrient supply (Wang et al., 2001; Jones et al., 2004). The accumulation of plant litter contributes to nutrient cycles in the soil (Bray and Gorham, 1964; Vitosek, 1984; Lowman, 1988). Plant roots play a role in regulating the development of microbial communities (Parmelee, 1995) and enhancing mineral weathering by exuding organic acids and enzymes in the rhizosphere (Courshesne and Gobran, 1997; Hinsinger et al., 1992; Richards, 1987). The production of organic acids influences chemical and geochemical processes such as nutrient release through metal chelating processes, retention, nutrient dissolution (Mench and Martin, 1991; Petersen and Bottger, 1991). The purpose of this study is to analyze the chemicalphysical characteristics of volcanic ash soils on the various perennial plant after the eruption in 2010.

\section{MATERIALS AND METHODS}

Soil sample in this study was taken in the southern slope of Mount Merapi, which was the area directly affected by 2010 eruption. The soil sample was taken from January to April 2016 at an altitude between 848-1155 MASL with a slope of 15 - 45\%. Sampling began with the determination of four locations that represented the type of vegetation found in the area affected by Merapi eruption. The four selected sampling sites had cinnamon (Cinnamomum burmanni), albizia (Albizia chinensis), bamboo (Gigantochloa apus Kurz.), and acacia (Acacia decurrens). For soil sampling, soil profile with the size of $1 \times 0.5 \times 0.5 \mathrm{~m}$ was made. Then the soil samples were taken from soil profile at a depth of $0-10 \mathrm{~cm}, 10-20 \mathrm{~cm}, 20-30 \mathrm{~cm}, 30-40 \mathrm{~cm}$, and $40-50 \mathrm{~cm}$. The soil samples were dried and sieved using $2 \mathrm{~mm}$ sieve and $0.5 \mathrm{~mm}$ sieve.

The soil chemical analysis were $\mathrm{pH} \mathrm{H}_{2} \mathrm{O}(1: 2.5)$ (Eviati \& Sulaeman, 2012); $\mathrm{pH} \mathrm{KCl} \mathrm{(1:2.5)} \mathrm{(ISRIC,}$ 2002); and $\mathrm{NaF}$ pH (1:50) (ISRIC, 2002). C-organic was analyzed using Walkey and Black method (ISRIC, 2002). Analysis of humic and fulvic acid using acid-base fractionation method (Kononova, 1966). Analysis of base cations and cation exchange capacity (CEC) was done by $1 \mathrm{M} \mathrm{NH}_{4} \mathrm{Cl}$ extracting solution (Ross \& Ketterings, 2011). Available potassium and sodium were measured by Flame photometer (Eviati \& Sulaeman, 2012) while available calcium and magnesium were measured by Atomic Absorption Spectrophotometer (Eviati \& Sulaeman, 2012). Available phosphorus analysis using Bray method 1 (ISRIC, 2002). Soil texture was analyzed by the piping method (Olmstead et al, 1930).

\section{RESULTS AND DISCUSSION}

Variability of Chemical and Physical Properties in Soil Depth

a). $\mathrm{pH}-\mathrm{H}_{2} \mathrm{O}, \mathrm{pH}-\mathrm{KCl}$, and $\mathrm{pH}-\mathrm{NaF}$

Based on the results of the soil $\mathrm{pH} \mathrm{H}_{2} \mathrm{O}$ analysis (Figure 1), it can be seen that the soil in the research site has a slightly acid-to-neutral $\mathrm{pH}$ value. In areas with cinnamon, the $\mathrm{pH}$ value ranges from 6.43 6.75 (slightly acid-neutral), albizia from $5.96-6.25$ (slightly acid), bamboo from 6.19 - 6.35 (slightly acid), and acacia from 5.93 - 6.55 (slightly acid). The probable cause of soil $\mathrm{pH}$ acidity in the study area was the parent material.

Land formed and developed in the area of Mount Merapi has a parent material derived from 


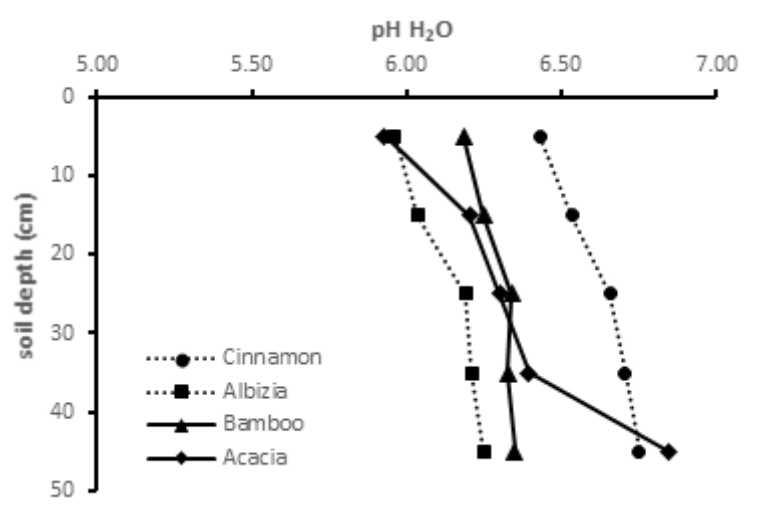

Figure 1. $\mathrm{pH}-\mathrm{H}_{2} \mathrm{O}$ vertical distribution pattern under four perennial plants

volcanic materials from the eruption of Merapi. The volcanic material comes from an intermediate andesitic magma with a content of $56 \% \mathrm{SiO}_{2}$ (Anda $\&$ Muhrizal, 2012; Fiantis, 2009). Therefore, the volcanic material of eruption will naturally experience the weathering process so that the land in the area of Mount Merapi will have an intermediate property. Based on the pattern of $\mathrm{pH}-\mathrm{H}_{2} \mathrm{O}$ distribution shown in Figure. 1, the overall pattern is similar. As the soil depth increased, the $\mathrm{pH}$ also increased. The soil $\mathrm{pH}$ distribution patterns are influenced by reactions occurring in the soil as the condition of organic matter decreases along with the deeper soil depth. Buckman \& Brady (1982) explain that the high content of organic matter at the soil surface can decrease soil pH. At each sample taken from the different depth, cinnamon had the highest $\mathrm{pH}$ value compared to the other plant species. This probably caused by the maturity level of organic cinnamon material is higher than the other organic vegetation. The addition of organic material to soil $\mathrm{pH}$ can increase or decrease the $\mathrm{pH}$ depending on the maturity level of organic matter. Immature organic material or organic matter that still undergoes decomposition process will decrease the soil $\mathrm{pH}$. During the decomposition process, organic matter will release organic acids that cause the decrease in soil $\mathrm{pH}$. The $\mathrm{pH}-\mathrm{H}_{2} \mathrm{O}$ distribution pattern in this study was not related to the vertical distribution of basic cations, such as $\mathrm{Ca}^{2+}, \mathrm{Mg}^{2+}, \mathrm{K}^{+}$, and $\mathrm{Na}^{+}$. This was caused by the decreasing amount of base cation as the increasing soil depth. On the contrary, the $\mathrm{pH}$ value is higher with increasing soil depth. As the number of base cations increases, the $\mathrm{pH}$ supposed to increase. However, there was no such phenomenon in this study.

Meanwhile, the $\mathrm{pH}-\mathrm{KCl}$ value in the four types of land (Figure 2) shows a slightly acidic value. The soil $\mathrm{pH}$ value in cinnamon ranged from 5.99 to 6.25 , albizia from 5.48 - 5.50 , bamboo from 5.33 - 5.63, and acacia from 5.39 - 5.52. Figure 2 displays a pattern of $\mathrm{pH}-\mathrm{KCl}$ distribution with decreasing value as the soil depth increased. The pattern of $\mathrm{pH} \mathrm{KCl}$ distribution was suspected to be influenced by the increasing number of $\mathrm{Al}^{3+}$ and $\mathrm{H}^{+}$ions as the soil depth increases.

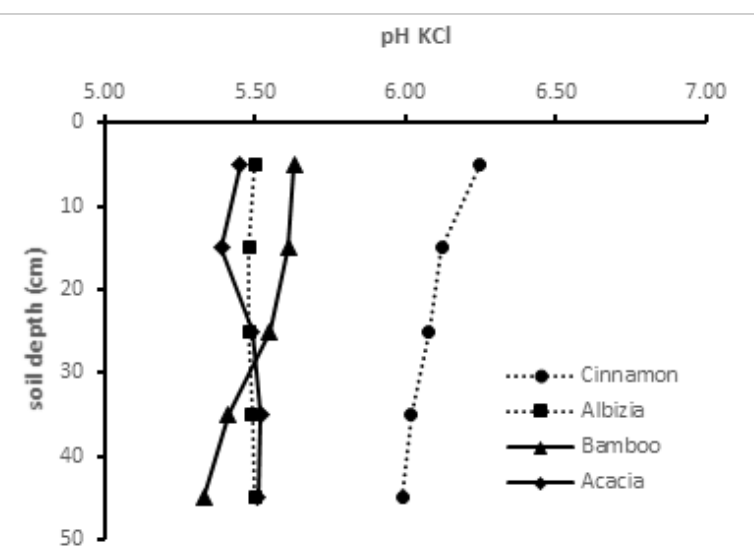

Figure 2. $\mathrm{pH}-\mathrm{KCl}$ vertical distribution pattern under four perennial plants

As can be seen in Figure 3, the $\mathrm{pH}-\mathrm{NaF}$ value of the area planted with cinnamon ranged from 10.33 - 10.65, albizia from 10.79 - 11.01, bamboo from 10.12 - 10.50, and acacia from 10.43 - 10.95. The overall $\mathrm{pH}$ value of $\mathrm{NaF}$ showed an irregular distribution pattern. This irregular pattern may be due to the uneven distribution of amorphous minerals in each depth of soil. The vertical $\mathrm{pH}$ pattern of $\mathrm{pH} \mathrm{NaF}$ is not affected by vegetation type but it is influenced by the presence of amorphous 
minerals. According to Soil Survey Staff (2014), the $\mathrm{pH}$ of $\mathrm{NaF}>9.4$ indicates that the soil contains amorphous minerals. This is supported by research of Yuliani, et al., (2017), which show that the mineral contents of allophane and imogolite clay of Mount Merapi were 27.3\% and 6.8\%, respectively.

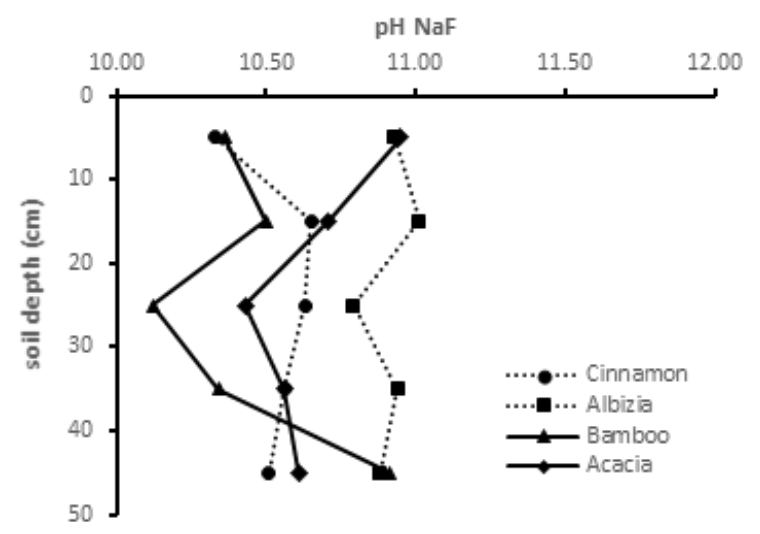

Figure 3.pH Na-F vertical distribution pattern under four perennial plants

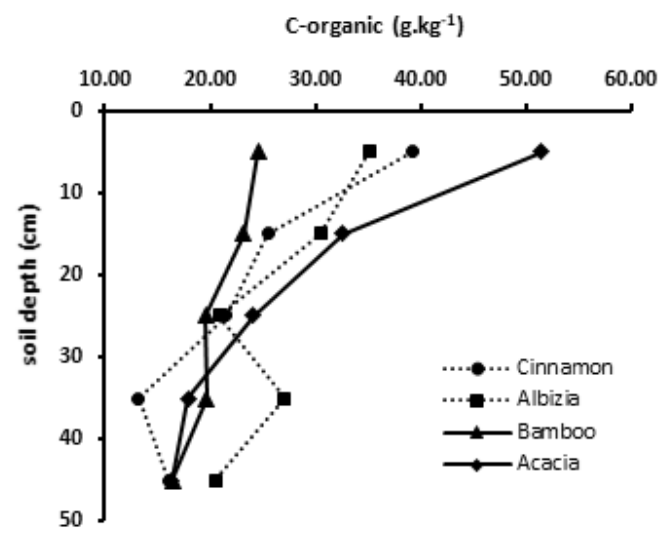

Figure 4. C-organic vertical distribution pattern under four perennial plants

\section{b). C-organic, humic and fulvic acid}

The C-organic content of area planted with four plant species is presented in Figure 4. The C-organic content of area planted with cinnamon ranged from 13.19 - $39.20 \mathrm{~g} \cdot \mathrm{kg}^{-1}$, albizia from 20.53 - 35.11 g. $\mathrm{kg}^{1}$, bamboo 16.39 - 24.61 g.kg ${ }^{1}$, and acacia 16.37 - $51.50 \mathrm{~g} \cdot \mathrm{kg}^{1}$. The pattern of C-organic distribution in the four types of vegetation has the same pattern. The C-organic content decreases gradually as the soil depth increases. The pattern of C-organic distribution is influenced by the vegetation as the source of soil organic matter. The top layer $(0-20 \mathrm{~cm})$ has the highest C-organic value due to the accumulation of organic matter from the decomposition of vegetation litter at each location. The top layer $(0-20 \mathrm{~cm})$ has the highest C-organic value due to the accumulation of organic matter resulting from litter decomposition and the production of vegetation biomass in a higher amount than the lower layer (Adugna and Abegaz, 2015; Turner, J. and N. L. James, 1975).

Albrecht et al., (1997) in his research state that the amount of organic matter is inversely proportional to soil depth. The higher the soil depth, the lower the $\mathrm{C}$ - organic value. The same results were also obtained from the research of Wang et al. (2017), which reported that the organic matter content decreased as the soil depth increased.

Levels of humic acid on the area planted with cinnamon ranged from $0.401-0.567 \mathrm{~g} \cdot \mathrm{kg}^{1}$, albizia from 0.251 - $0.612 \mathrm{~g} . \mathrm{kg}^{1}$, bamboo from 0.328 $0.518 \mathrm{~g} \cdot \mathrm{kg}^{1}$, and acacia from $0.250-0.408 \mathrm{~g} \cdot \mathrm{kg}^{1}$ (Figure 5). Meanwhile, the level of fulvic acid on the area planted with cinnamon ranged from 0.357 - $0.532 \mathrm{~g} \cdot \mathrm{kg}^{1}$, albizia from 0.546 - $0.921 \mathrm{~g} \cdot \mathrm{kg}^{1}$, bamboo from $0.327-0.574 \mathrm{~g} \cdot \mathrm{kg}^{1}$, and acacia from $0.333-0.864{\mathrm{~g} . \mathrm{kg}^{1}}^{1}$ ) (Figure 6). The levels of humic acid and fulvic acid varied at each depth and show an irregular distribution pattern. This condition could be caused by the level of humidification

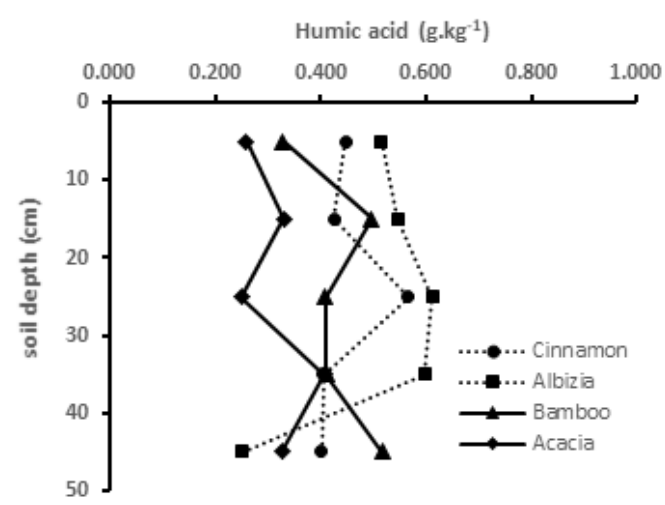

Figure 5. Humic acids vertical distribution pattern under four perennial plants 


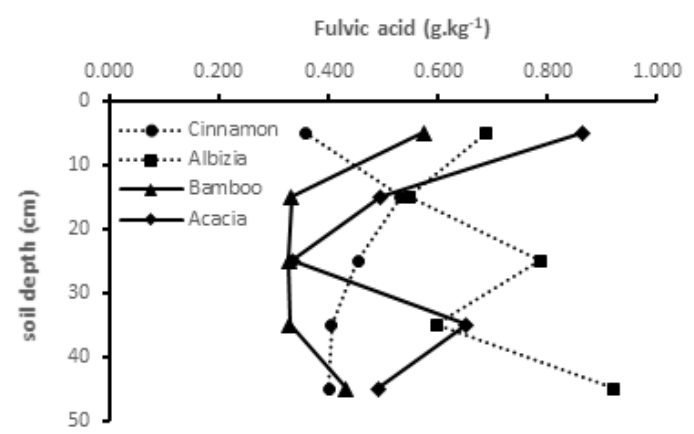

Figure 6. Fulvic acids vertical distribution pattern under four perennial plants

of different organic materials on each layer. In overall, the highest humic acid value at each depth was obtained from albizia plants while acacia and albizia plants had the highest fulvic acid value at each depth.

\section{c). Cation Exchange Capacity (CEC) and Base Cation Availability}

The results show that the CEC at area planted with cinnamon ranged from $6.62-8.63 \mathrm{cmol} . \mathrm{kg}^{1}$ (low), albizia from $3.53-4.77 \mathrm{cmol} . \mathrm{kg}^{1}$ (very low), bamboo $0.41-3.28 \mathrm{cmol}^{.} \mathrm{kg}^{1}$ (very low), and acacia from $2.25-5.03 \mathrm{cmol}^{.} \mathrm{kg}^{1}$ ) (very low) (Figure 7). The distribution pattern of CEC in all four locations formed a declining pattern with increasing soil depth. The soil CEC value is influenced by organic matter content and the type of clay mineral (Helling et.al, 1964; Ulusoy et al, 2016). The soil CEC value has interconnected relation to other soil properties such as texture and organic matter.

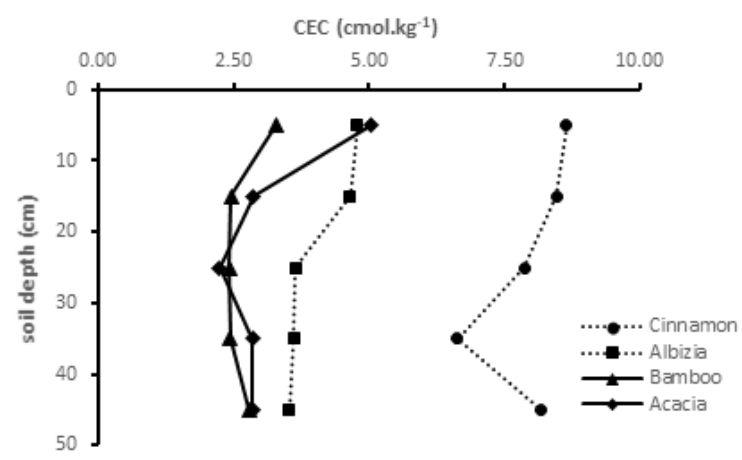

Figure 7.CEC vertical distribution pattern under four perennial plants
The percentage of the sand fraction influences the soil CEC value. Figure 14 shows that the particle distribution was dominated by the sand fraction at each depth of the soil. The more the sand fraction, the lower the CEC value. In contrast, as the number of clay fractions increases, the CEC value also increases (Ersahin, et.al, 2006; Leo et al., 2011). Organic materials can also affect the soil CEC value because organic materials give negative charges to the soil CEC. The more the organic material, the higher the CEC value. This is shown by the same pattern between CEC distribution and the C-organic distribution, where they were inversely proportional to the soil depth.

The number of available $\mathrm{K}^{+}$cations at area planted with cinnamon ranged from $0.77-1.22$ cmol. $\mathrm{kg}^{1}$ (high-very high), albizia from $0.62-0.94$ cmol. $\mathrm{kg}^{1}$ (high), bamboo from $0.35-0.57 \mathrm{cmol}$. $\mathrm{kg}^{1}$ (medium), and acacia $0.56-0.99 \mathrm{cmol}^{.} \mathrm{kg}^{-1}$ (high) (Figure 8). Similarly, the amount of $\mathrm{Na}^{+}$ cations in the research sites was very high. The number of available $\mathrm{Na}^{+}$cations at area planted with cinnamon ranged from $1.22-2.04 \mathrm{cmol} . \mathrm{kg}^{-1}$ (very high), albizia from $1.00-1.70 \mathrm{cmol} . \mathrm{kg}^{1}$ (very high), bamboo from $0.52-0.87 \mathrm{cmol}^{. \mathrm{kg}^{1}}$ (high), and acacia $0.98-1.71 \mathrm{cmol}^{. \mathrm{kg}^{1}}$ (very high) (Figure 9). Meanwhile, the amount of available $\mathrm{Ca}^{2+}$ cation at the area planted with cinnamon ranged from $0.25-4.74 \mathrm{cmol}^{.} \mathrm{kg}^{-1}$ (very low - low), albizia from 0.13 - $2.90 \mathrm{cmol}^{\mathrm{kg}} \mathrm{kg}^{1}$ (very low - low), bamboo from $1.87-2.23 \mathrm{cmol} . \mathrm{kg}^{1}$ ) (very low - low), and acacia from $1.98-2.59 \mathrm{cmol}^{. \mathrm{kg}^{1}}$ (very low - low) (Figure 10). The number of available $\mathrm{Mg}^{2+}$ cations at area planted with cinnamon ranged from 0.14 $0.24 \mathrm{cmol}_{\mathrm{kg}} \mathrm{kg}^{-1}$ (very low), albizia $0.09-0.11 \mathrm{cmol}$. $\mathrm{kg}^{-1}$ (very low), bamboo $0.08-0.09$ cmol. $\mathrm{kg}^{1}$ (very low), and acacia $0.09-0.20 \mathrm{cmol}^{. \mathrm{kg}^{1}}$ (very low) (Figure 11). In general, the highest number of $\mathrm{K}^{+}$, $\mathrm{Na}^{+}, \mathrm{Ca}^{2+}$, and $\mathrm{Mg}^{2+}$ were in the top layer, and the number decreased in the lower layer. Therefore, the 


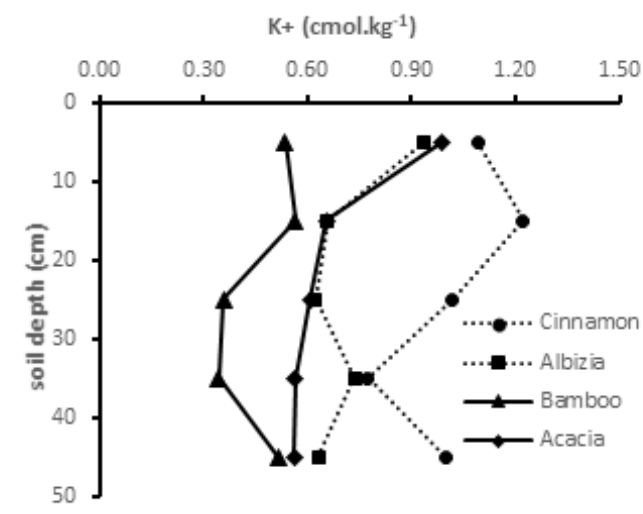

figure $8 . \mathrm{K}^{+}$vertical distribution pattern under four perennial plants

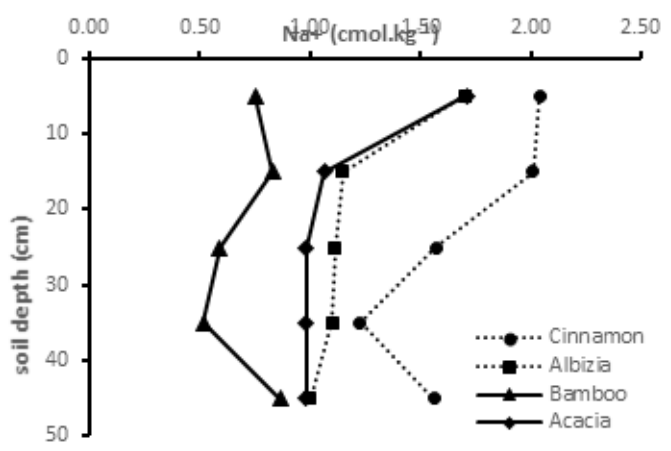

Figure 9. $\mathrm{Na}^{+}$vertical distribution pattern under four perennia plants

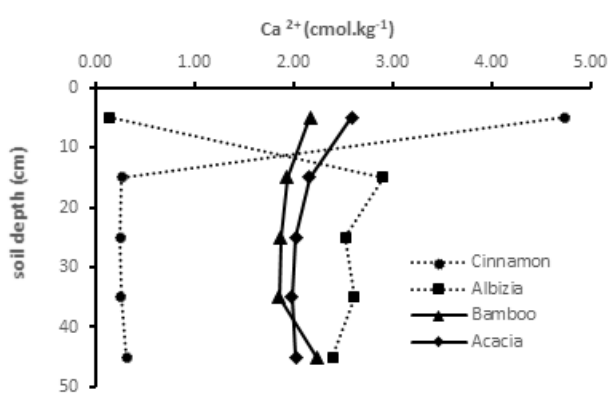

Figure 10. $\mathrm{Ca}^{2+}$ vertical distribution pattern under four perennial plants

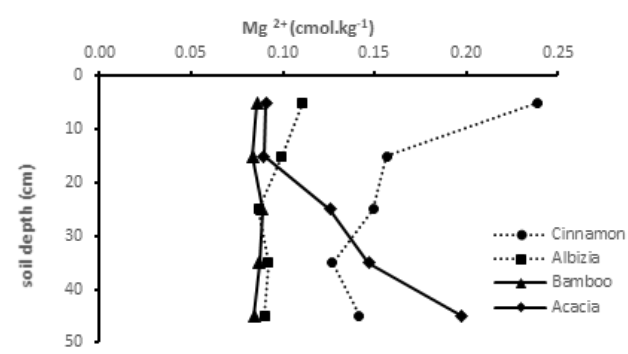

Figure $11 . \mathrm{Mg}^{2+}$ vertical distribution pattern under four perennial plants basic cation distribution provides a vertical distribution pattern whose value decreases with increasing depth of soil. The vertical distribution pattern of base cation availability has a similar shape to the vertical distribution pattern of the CEC.

The amount of $\mathrm{K}^{+}$and $\mathrm{Na}^{+}$cations were high, which was influenced by the type of minerals in the soil. Study conducted by Aini et al. (2016) shows that the pyroclastic material of 2010 Merapi eruption is composed of plagioclase, which is a primary mineral that is easy to decompose and rich in $\mathrm{Na}$ nutrients. Meanwhile, the $\mathrm{K}^{+}$cations are derived from the weathering of the volcanic glass.

\section{d). Base Saturation}

The base saturation at the four research sites had varying values (Figure 12). Base saturation

obtained from area planted with cinnamon ranged from 36.96 - 93.99\%, albizia from 60.44 - $126.56 \%$, bamboo from 108.55 - 139.40\%, and acacia from $107.05-166.31 \%$. The base saturation in the research sites had a high value because the soil contains a mineral that is easily decomposed. The vertical distribution pattern of saturation shows a wide range, which is influenced by the number of base cations availability and the various CECs. Bear et al., (1945) suggest that one of the indications of fertile soil is having an alkaline saturation of $>65 \%$. This is supported by Leticia et al. (2014), which state that the soils with high saturation will have a high fertility rate as well.

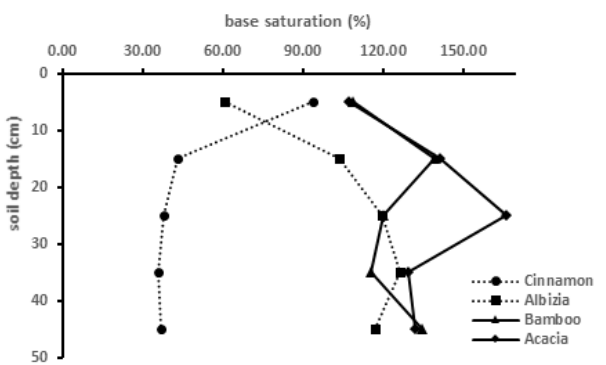

Figure 12. Base saturation vertical distribution pattern under four perennial plants 


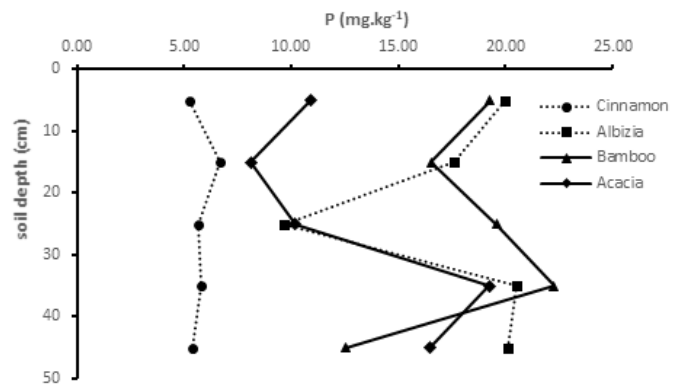

Figure 13. Available $P$ vertical distribution pattern under four perennial plants

\section{e). Available P}

The results show that the available $\mathrm{P}$ on the four research sites had a very low value (Figure 13). P level obtained from the area planted with cinnamon ranged from $\left.5.27-6.69 \mathrm{mg} . \mathrm{kg}^{1}\right)$ (low), albizia from 9.69 - $20.51 \mathrm{mg} \cdot \mathrm{kg}^{1}$ (medium - high), bamboo (12.53 - $\left.16.65 \mathrm{mg} . \mathrm{kg}^{1}\right)$ (medium - high), and acacia from $13.55-25.36 \mathrm{mg} . \mathrm{kg}^{1}$ ) (high - very high). The vertical distribution pattern of $\mathrm{P}$ available at the study site showed an irregular pattern, which is influenced by the irregular distribution of $\mathrm{P}$ source minerals on the soil.

\section{f). Distribution of Soil Particle Size}

The distribution pattern of the sand fraction dominates at the study sites as shown in Figure 14. At location planted with cinnamon, the sand content ranged from $45.68-58.48 \%$. Meanwhile, the sand content at the location planted with albizia, bamboo, and acacia were 72.72 - 84.80\%, 74.77 - $85.92 \%$, and 65.57 - 87.39\%, respectively. The location of planted with albizia, bamboo, and acacia had a higher distribution of sand than cinnamon. This is because the three research sites were directly affected by 2010 Merapi eruption. The lowest sand fraction content was obtained at layer 0 - 10 and increased with increasing of soil depth. This vertical distribution is influenced by volcanic material sedimentation in the region.

The distribution pattern of silt fraction in the four research sites is presented in Figure 15. At the location planted with cinnamon, the silt content ranged from 32.45 to $50.27 \%$. Meanwhile, the silt fraction on the location planted with albizia, bamboo, and acacia were $13.52-25.15 \%, 12.21$ - 24.16\%, and $9.97-30.45 \%$, respectively. The highest sand fraction content was obtained at layer 0 - 10 and decreased with increasing of soil depth. The pattern of clay fraction distribution in the four study sites is presented in Figure 16. Clay fraction content has the least amount compared

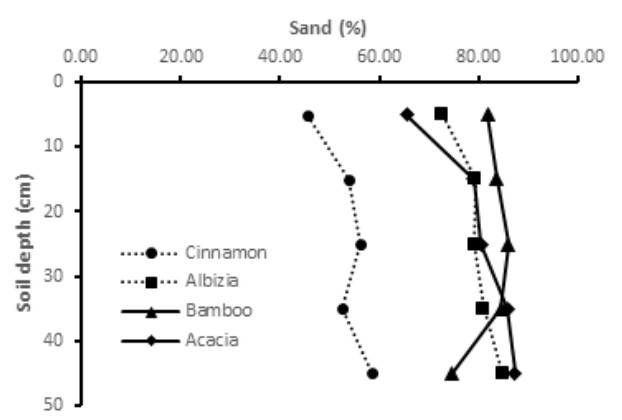

Figure 14. Vertical distribution pattern of sand fraction under four perennial plants

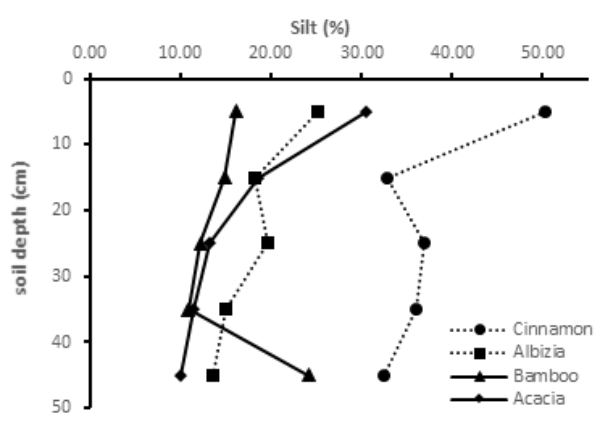

Figure 15. Vertical distribution pattern of silt fraction under four perennial plants

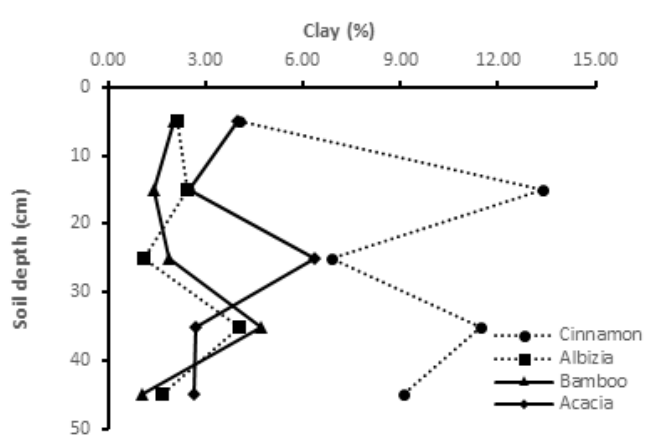

Figure 16. Vertical distribution pattern of clay fraction under four perennial plants 
to sand and silt. At the location planted with location planted with cinnamon >albizia > acacia > cinnamon, the clay content ranged from 4.05 - bamboo and the clay fraction on location planted $13.39 \%$. Meanwhile, the respective clay content with cinnamon $>$ acacia $>$ albizia $>$ bamboo. The at the location planted with albizia, bamboo, and acacia were $1.09-4.03 \%, 1.07-2.03 \%$, and 2.48 - 3.97\%. The particle size distribution composition at the four research sites was dominated by sand, while the clay was the lowest fraction of soil. This is similar with the study conducted by Wardoyo and Santosa (2016), which shows that sand has the highest fraction $(82.35 \%)$ followed by silt $(8.78 \%)$ and clay $(1.62 \%)$. $\mathrm{pH}-\mathrm{H}_{2} \mathrm{O}$ and $\mathrm{pH}-\mathrm{KCl}$ values were significantly influenced by the vegetation type. The $\mathrm{pH}-\mathrm{H}_{2} \mathrm{O}$ values on location planted with cinnamon > acacia $>$ bamboo > albizia while the $\mathrm{pH}-\mathrm{KCl}$ on location planted with cinnamon > acacia > bamboo > albizia.

The levels of C-organic, C-humic acid, C-fulvic acid and $\mathrm{AH} / \mathrm{AF}$ were significantly influenced by the vegetation type. The respective C-organic, Chumic, C-fulvic, and AH/AF values on location planted with acacia > albizia > cinnamon > bamboo;

The Effect of Vegetation on the Soil Chemical and Physical Properties

albizia > cinnamon > bamboo > acacia; albizia > acacia $>$ cinnamon $>$ bamboo, and bamboo $>$ cin-

The statistical analysis of the effect of vegetation type on soil physical and chemical properties is presented in Table 1. The soil particle size distribution is significantly influenced by the vegetation type, with the distribution value of sand fraction on location planted with bamboo plant > acacia> albizia > cinnamon. Meanwhile, the silt fraction on namon > albizia > acacia. Moreover, CEC and base cations availability were significantly influenced by vegetation type. The CEC values on location planted with cinnamon > albizia > acacia > bamboo. Meanwhile, the $\mathrm{K}$ levels on location planted with cinnamon > albizia > acacia > bamboo, while the $\mathrm{Na}$ content on location planted with cinnamon Table 1. Soil physical and chemical properties under four perennial plants

\begin{tabular}{|c|c|c|c|c|}
\hline \multirow{2}{*}{ Soil Properties } & \multicolumn{4}{|c|}{ Tipe Vegetasi } \\
\hline & Cinnamon & Albizia & Bamboo & Acacia \\
\hline Sand (\%) & $53.34 \mathrm{c}$ & $79.43 \mathrm{~b}$ & $82.14 \mathrm{a}$ & $79.65 b$ \\
\hline Silt (\%) & $33.79 \mathrm{a}$ & $18.29 b$ & $15.64 d$ & $16.72 c$ \\
\hline Clay (\%) & $12.86 \mathrm{a}$ & $2.28 \mathrm{c}$ & $2.21 \mathrm{c}$ & $3.62 b$ \\
\hline $\mathrm{pH} \mathrm{H}_{2} \mathrm{O}$ & $6.61 \mathrm{a}$ & $6.12 b$ & $6.29 b$ & $6.33 \mathrm{~b}$ \\
\hline $\mathrm{pH} \mathrm{KCl}$ & $6.08 \mathrm{a}$ & $5.47 \mathrm{~b}$ & $5.48 \mathrm{~b}$ & $5.49 \mathrm{~b}$ \\
\hline pH NaF & $10.53 \mathrm{a}$ & $10.94 \mathrm{a}$ & $10.44 \mathrm{a}$ & $10.53 a$ \\
\hline C-org $\left(g \cdot k^{-1}\right)$ & $23.09 c$ & $26.82 b$ & $20.70 d$ & $28.52 \mathrm{a}$ \\
\hline Humic acid (g.kg-1) & $0.44 b$ & $0.50 \mathrm{a}$ & $0.43 c$ & $0.31 d$ \\
\hline Fulvic acid $\left(g \cdot \mathrm{kg}^{-1}\right)$ & $0.43 c$ & $0.70 \mathrm{a}$ & $0.39 \mathrm{~d}$ & $0.56 \mathrm{~b}$ \\
\hline $\mathrm{AH} / \mathrm{AF}$ & $1.06 \mathrm{~b}$ & $0.76 \mathrm{c}$ & $1.15 \mathrm{a}$ & $0.60 d$ \\
\hline CEC (cmol. $\left.\mathrm{kg}^{-1}\right)$ & $7.94 a$ & $4.04 \mathrm{~b}$ & $2.67 d$ & $3.17 c$ \\
\hline $\left.\mathrm{K}\left(\mathrm{cmol}^{\mathrm{kg}}\right)^{-1}\right)$ & $1.02 \mathrm{a}$ & $0.71 \mathrm{~b}$ & $0.46 d$ & $0.67 c$ \\
\hline $\mathrm{Na}\left(\mathrm{cmol}^{\mathrm{kg}}{ }^{-1}\right)$ & $1.68 \mathrm{a}$ & $1.21 \mathrm{~b}$ & $0.71 d$ & $1.14 \mathrm{c}$ \\
\hline $\mathrm{Ca}\left(\mathrm{cmol}^{\mathrm{kgg}}{ }^{-1}\right)$ & $1.16 c$ & $2.11 \mathrm{a}$ & $2.00 \mathrm{~b}$ & $2.15 \mathrm{a}$ \\
\hline $\mathrm{Mg}\left(\mathrm{cmol}^{\mathrm{kgg}}{ }^{-1}\right)$ & $0.16 \mathrm{a}$ & $0.09 c$ & $0.08 c$ & $0.13 b$ \\
\hline Available P $\left(\mathrm{mg} \cdot \mathrm{kg}^{-1}\right)$ & $5.77 d$ & $17.56 \mathrm{~b}$ & $18.04 \mathrm{a}$ & $12.98 c$ \\
\hline Base saturation (\%) & $49.59 c$ & $105.40 \mathrm{~b}$ & $123.65 \mathrm{a}$ & $135.25 \mathrm{a}$ \\
\hline
\end{tabular}


$>$ albizia $>$ acacia $>$ bamboo, the $\mathrm{Ca}$ content on location planted with acacia > albizia > bamboo $>$ cinnamon, the Mg content on location planted with cinnamon plant $>$ acacia $>$ albizia $>$ bamboo, the available $\mathrm{P}$ content on location planted with bamboo > albizia > acacia> cinnamon, the base saturation on location planted with acacia $>$ bamboo > albizia > cinnamon. However, the $\mathrm{pH}$ of $\mathrm{NaF}$ was not significantly influenced by vegetation type. Cinnamon is a plant that gives the strongest influence in the improvement of soil chemical-physical properties compared to the other three types of vegetation.

\section{CONCLUSION}

Cinnamon is a plant that gives the strongest influence in the improvement of soil chemicalphysical properties compared to the other three types of vegetation. The results of soil chemicalphysical analysis show that $\mathrm{pH} \mathrm{H}_{2} \mathrm{O}, \mathrm{pH} \mathrm{KCl}, \mathrm{C}$ organic, humic acid and fulvic acid, CEC, K, Na, $\mathrm{Ca}, \mathrm{Mg}$, available $\mathrm{P}$, base saturation, and particle size distribution were significantly affected by vegetation type. Meanwhile, the $\mathrm{pH}$ of $\mathrm{NaF}$ was not significantly influenced by vegetation type. The $\mathrm{pH} \mathrm{H}_{2} \mathrm{O}$ and the distribution of sand fractions had positive distribution patterns, where the value increased as the depth of soil increased. However, $\mathrm{pH} \mathrm{KCl,} \mathrm{C-organic,} \mathrm{CEC,} \mathrm{base} \mathrm{cation} \mathrm{availability,}$ and the distribution of silt fraction had negative distribution patterns, where the value decreased with increasing soil depth.

\section{ACKNOWLEDGMENTS}

We would like to express our gratitude to the Directorate General of Higher Education who has assisted the fund in conducting this research through research contract no: 015/SP2H/LT/ DRPM/II/2016.

\section{REFERENCES}

Adugna, A. \& A. Abegaz. 2015. Effects of soil depth on the dynamcs of selected soil propeerties among the highlans resources of Northeast Wollega, Ethiopia: are these sign of degradation?. Solid Earth Discuss (7): 2011-2035.

Anda, M. \& M. Sarwani. 2012. Mineralogical, chemical composition and dissolution of fresh ash eruption: new potential source of nutrient. Soil Sci Soc.Am. J.76:733-747.

Aweto, A.0. 1981. Secondary succession and soil fertiity restoration in south western Nigeria. Journal of ecology 69: 601-607.

Bear, F. E., A.L. Prince \& J.L. Malcom. 1945. The potassium needs of New Jersey soils. New Jersey Agric. Exp. Stn. Bull. 721.

Buckman, H.O. \& N.C. Brady. 1982. The Nature and Properties of Soils. The Macmillan company. New York.

Bray, J.R\& E. Gorham. 1964. Litter productionin forest of thr world. Advance in ecologycal 101-157.

Courchesne, F. \& Gobran GR.1997. Mineralogy of bulk and rhizosfer soil in a Norway Spruce stand. Soil Sci.Soc.Am.J.61:1245-1249.

Ersahin, S., H. Gunal, T. Kutlu, B. Yetgin, \& S. Coban. 2006. Estimating spesific surface area and cation exchange capacity in soils using fractal dimention of particle size distribution. Geoderma 136: 588-597.

Eviati \& Sulaeman. 2012. Technical Guide Issue II Chemical Analysis of Soil, Plants, Water, and Fertilizer. Agency for Agricultural Research and Development, Ministry of Agriculture Republic Indonesia.

Fiantis, D., M. Nelson, Van Ranst, E., J. Shamshuddin, \& N.P. Qafoku, 2009. Chemical Weathering of New Piroclastic Deposit from Mt. Merapi (Java), Indonesia. J.Mt.Sci. (2009) 6: 240-254.

Hinsinger P., B. Jaillard \& JE Duffey. 1992. Rapid weathering of trioctahedral mica by the roots of ryegrass. Soil.Sci.Soc. Am.J.56:977-982.

Helling, C., G. Chesters, \& R.B. Corey. 1964. Contribution of organic matter and clay to soil cation exchange capacity as affected by the $\mathrm{pH}$ of saturating solution. Soil Science Society of America Journal 28: 4.

ISRIC FAO. 2002. Procedures for soil analysis. ISRIC Technical Paper.

Jones, D. L., A. Hodge \& Y. Kuzyakov. 2004. Plant and mycorrhizal regulation of rhizodepostion. New phytologist 163:459-480.

Kononova, M.M. 1996. Soil organic matter. Its nature its role in soil formation and soil fertility. Translated by T.Z. Novakowski and A.C.D. Newman. Pergamon Press, Oxford. Pp 544.

Leticia, S.S., E.K. David \& S. Uttam. 2014. Cation Exchange Capacity and Base Saturation. The University of Georgia. UGA Extension Circular 1040.

Lowman, M.D. 1988. Litterfall and leaf decay in three Australian rainforest formation. Journal of Ecology 76:451-465.

Olmstead, L.B., L.T. Alexander \& H.E. Middleton. 1930. A pipette methode of mechanical analysis of soil based on improved dispersion prosedure. Techical bulletin No 170 United States Departemen of Agriculture.

Parmelee, R.W. 1995. Soil fauna: linking different levels of the ecolgycal hierarchy. In Jones \& Lawton J.H. Linking species and ecosystem: 107-116.

Richard, B.N. 1987. The microbiology of terrestrial ecosystem. John Wiley and Sons. New York. Pp 222-254. 
Ross, D. \& Q. Katterings. 2011. Recommended Methods for Determining Soil Cation Exchange Capacity. In: Recommended Soil Testing Procedures For The Northeastren United States, Sims,

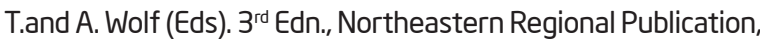
USA., pp: 75-86.

Mench, M. \& E. Martin. 1991. Mobilization of cadmium and other metals from two soils by root exudates by Zea mays L., Nicotina tabacum L, and Nicotica rustica L. Plant Soil 132: 187-196.

Newhall, C.G., S. Bronto, B. Alloway, N.G. Banks, I. Bahar, M.A. del Marmol, R.D. Hadisantono, R.T. Holcomb, J. McGeehin, J.N. Miksic, M. Rubin, S.D. Sayudi, R. Sukhyar, S. Andreastuti, S. Tilling, R. Torley, R. Trimble, \& D. Wirakusumah. 2000. 10,000 years of explosive eruptions of Merapi volcano, Central Java: archaeological and modern implications. J. Volcanol. Geoth. Res. 100 (1-4):9-50.

Petersen, W. \& Bottger M. 1991. Contribution of organic acids to acidification of the rhizosphere of maize seedlings. Plant Soil 132: 159-163.

Soil Survey Staff. 2014b. Kellogg Soil Survey Laboratory Methods Manual. Soil Survey Investigations Report. No. 42 (Version 5.0). R. Burt and Soil Survey Staff (ed.). U.S. Department of Agriculture, Natural Resources Conservation Service. P. 1031.

Surono, P. Jousset, J. Pallister, M. Boichu, M. F. Buongiorno, A. Budisantoso, F. Costa, S. Andreastuti, F. Prata, D. Schneider, L. Clarisse, H. Humaida, S. Sumarti, C. Bignami, J. Griswold, S. Carn, C. Oppenheimer, \& F. Lavigne. 2012. The 2010 explosive eruption of Java's Merapi Volcano- A '100-year' event. Journal of Volcanology and Geothermal Research. 241-242:121-135.

Turner, J. \& J.N. Long. 1975. Accumulations of organic matter in a series of Douglas-fir stands. Can. J. For. Res. 5(4): 681-690.
Ulusoy, Y., Y. Tekin, Z. Tumsavas, \&A.M. Mouazen. 2016. Prediction of soil cation exchange capacity using visible and near infrared spectroscopy. Biosystem engineering 2016:1-15.

Vitousek, P.M. 1984. Litterfall, nutrient cycling and nutrient limitation in tropical forest. Ecology 65: 285-298.

Voight, B., K.D. Young, D.Hidayat, M.A. Subandrio, A. Purbawinata, Ratdomopurbo, S. Panut, D.S. Sayudi, R. LaHusen, J. Maso, T.L. Murray, M. Dejean, M. Iguchi, \& K. Ishihara. 2000. Deformation and seismic precusors to dome-collapse and mountain collapse nuees ardentes at Merapi Volcano, Java, Indonesia, 1994-1998. Journal of Volcano. And Geothermal Research. 100: 261-287. Wang, Z.Y. A. Gottlein \& G. Bartonek. 2001.Effects of growing roots of Norway spruce and European beech on rhizosphere soil solution chemistry. Journal of plant nutrition and soil science 164: 35-41.

Wang, Z., Y. Hu, R. Wang, S. Guo, L. Du, M. Zhao, \& Z. Yao. 2017. Soil organic carbon on the fragmented Chinese Loess Plateau: combining effects of vegetation types and topographic positions. Soil \& Tillage Research 174: 1-5.

Wardoyo, S.S. \& A.Z.P.B. Santosa. 2016. Environmental adaptability of Canavalia virosa and Flemingia congesta to sandy ash soil of Merapi Volcano, Java. Journal of Degraded and Mining Land Management vol 3 (4): 665-668.

Yuliani, N., E. Hanudin, \& B.H. Purwanto. 2017. Chemical characteristics and morphology of amorphous materials derived from different parent materials from Central Java, Indonesia. Int. J. Soil Sci. 